\title{
Pharmacognostic profile of the leaf of Ageratum conyzoides
}

\author{
Rosamund Jyrwa, Nungshioba Jamir, Muslek Uddin Mazumder, P. Khazeo, K. Nusalu Puro, \\ Lalzikpuii Sailo*
}

Department of Pharmacy, Regional Institute of Paramedical and Nursing Sciences, Zemabawk 796017, Mizoram, India

Corresponding author: zikpuii08@gmail.com

\begin{abstract}
Ageratum conyzoides Linn. (Asteraceae), commonly known as billy-goat weed and white weed, is an important plant in the Indian traditional medicine. It is widely used for the treatment of dysentery, diarrhoea, injuries, cuts, snake bites, pneumonia, and as an insecticide and nematicide. This work was an attempt to standardise and identify the leaf samples.: The fresh leaves of $A$. conyzoides were collected, from which macroscopic and quantitative microscopic studies were performed by using standard procedure to determine the diagnostic features for the identification and standardization. The leaves were found to have ovate, sub-acute and crenate with ciliate margins, the stem is greenish yellow covered with fine white hairs and flowers are white to mauve in colour, arranged in close terminal inflorescences. Light and electron microscopic data of the cross-section showed the presence of vascular bundles, parenchyma cells, collenchyma cells and multicellular non-glandular trichomes, upper and lower epidermal cells. Anomocytic stomata are seen in both upper and lower epidermis. Quantitative microscopic (such as Vein islet and vein termination, stomata number and stomatal index) were also determined after the leaves were boiled in chloral hydrate solution to remove the chlorophyll. Our results would be important in authentication of the leaf and analysing the pharmacopoeial standards of A. conyzoides.
\end{abstract}

Keywords: Asteraceae, billygoat weed, morphology, microscopy, anomocytic.

\section{INTRODUCTION}

Medicinal plants are considered as a rich resource of ingredient for the use in drug development either pharmacopoeial, non-pharmacopeial or synthetic drug (Khare, 2007). It is the use of plants for medicinal purposes, and the research of such uses that form tha basis of many drug discoveries (Zahid, 2016). Many plants are considered as vital source of nutrition and as a result they are recommended for their therapeutic values (Khare, 2007).

Natural products are those chemical organic substances which generally originate in nature and are produce by living organism (Chintoju, 2015). It can also produce either naturally synthesis or semi-synthesis process which play an important role in medicinal chemistry for delivery the target in drug discovery process and drug development. Chemically, the natural product also con- tains various types of compounds such as terpenoids, peptides, proteins, carbohydrates, amino acids, nucleic acid, lipids, polyketides and so forth.

Therapeutic efficacy of medicinal plant depends both on quality and quantity of chemical constituents (Chopra, 1956). Wrong identification of natural product or herbal medicines lead to misuse of it (Chintoju, 2015) These is due to common error, i.e. the vernacular name is given to two or more than two or more entirely different species. These entire main problems can be solved by the pharmacognostic studies of plant materials. Asteraceae is the vast plant family which roughly comprises of 1500 genera and 2500 species in different habitat (Souza and Lorenz, 2012).

Ageratum is one of the genera which belong to the family Asteraceae and consist 30 species (Okunade, 2002). Among the species, Ageratum conyzoides L. is commonly known as billy goat weed in English words "a geras" meaning non-aging and conyzoides from "Konyz" 
the Greek name of Inula helenium which the plant resembles (Santosh, 2016). A. conyzoides is a tropical plant found commonly in western and eastern region of the African continent, in some region of Asia and South America (Bhatt et al., 2012). It is polymorphic, annual aromatic weed of cultivated field (Sousa et al., 2004).

The leaves of plant are used in variety of conditions, i.e. wound (Dash and Murthy, 2011a,b), sore, haemorrhoids, and are also used as styptic and anti-dysenteric, antibacterial (Woldeyes et al., 2012) anti-inflammatory, analgesic, antipyretic, antiparmedic, gastroprotective, anti-ulcer (Mahmood, 2005), insecticidal (Moreira, 2007), antihelmintic and mosquito repellent (Jonarthanan, 2016).

\section{MATERIALS AND METHOdS}

\section{Plants materials}

Fresh leaves of Ageratum conyzoides plant were collected from in and around Zemabawk campus of Regional Institute of Paramedical and Nursing Sciences, Aizawl, Mizoram, India. The identity of the plant was authenticated by a botanist at the Botanical Survey of India, Shillong. A voucher specimen of these plant have been deposited in the Department of Pharmacy, RIPANS with Reference no: BSI/ERC/TECH/Plant Iden./2018/136.

\section{Macroscopic analysis}

The following macroscopic observation of the fresh leaves was done. The shape and size, colour, odour, taste, surface, characters, texture, the apex, margin, and base were noted (Trease \& Evans, 2002).

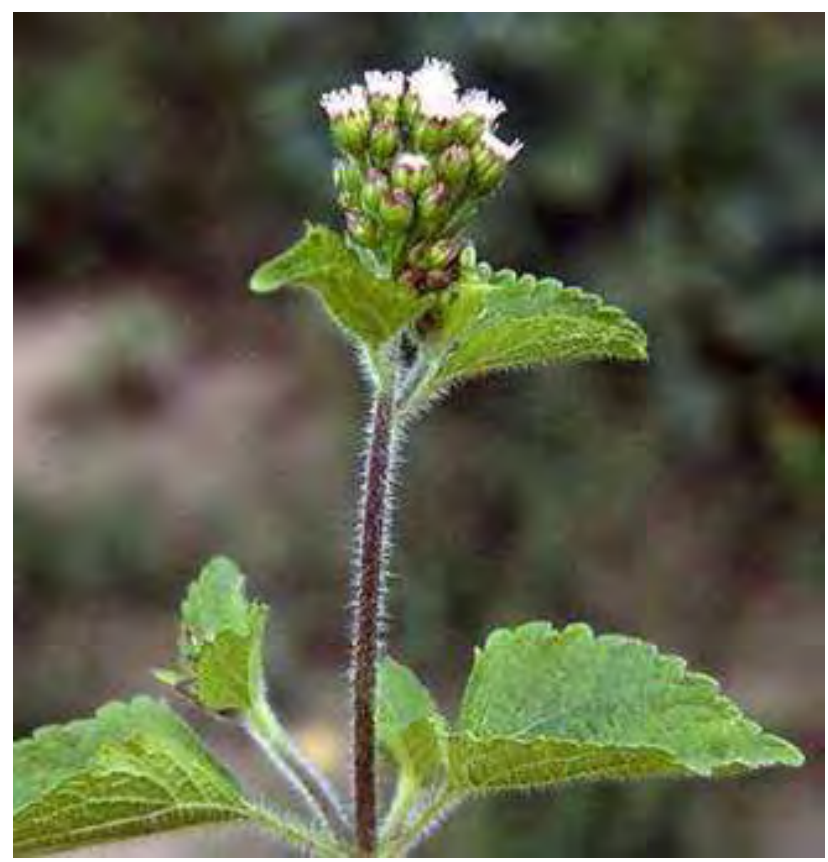

Figure 1: Aerial part of Ageratum conyzoides.

\section{Microscopic analysis}

Macroscopic evaluation was carried out by preparing thin section of leaf and was further treated with chloral hydrate solution, mounted with glycerine and was observed under projection microscope (10X, 40X). The presence of the following cells were observed; epidermal cell (upper and lower), xylem, phloem, collenchyma and parenchyma cells. The transverse sections of the fresh leaves through the lamina the midrib were mounted, observed and capturing the image and diagnostic characteristics features were recorded.

\section{Determination of stomatal number}

The fresh leaf section was cut, cleared and was boiled with chloral hydrate solution. Both Upper and lower were peeled separately by sing forceps. It was then kept ion the slides and was mounted with glycerine water. Further the slide contain pieces of the cleared leaf was placed on the stages and was observed under projection microscopes (10x, 40x). The epidermal cells and stomata were counted in an area of $60 \times 60 \mathrm{~mm}$. The cells were included if at last half of it area may lies within the given square. The result was recorded and per sq. $\mathrm{mm}$ was calculated.

\section{Determination of stomatal index}

Some pieces of the fresh leaves were cut and were boiled by using chloral hydrate solution. Both upper and lower epidermis was peeled separately by mean of forceps. Then it was kept on the slide and mounted in glycerine water. The slides were placed with cleared leaf on

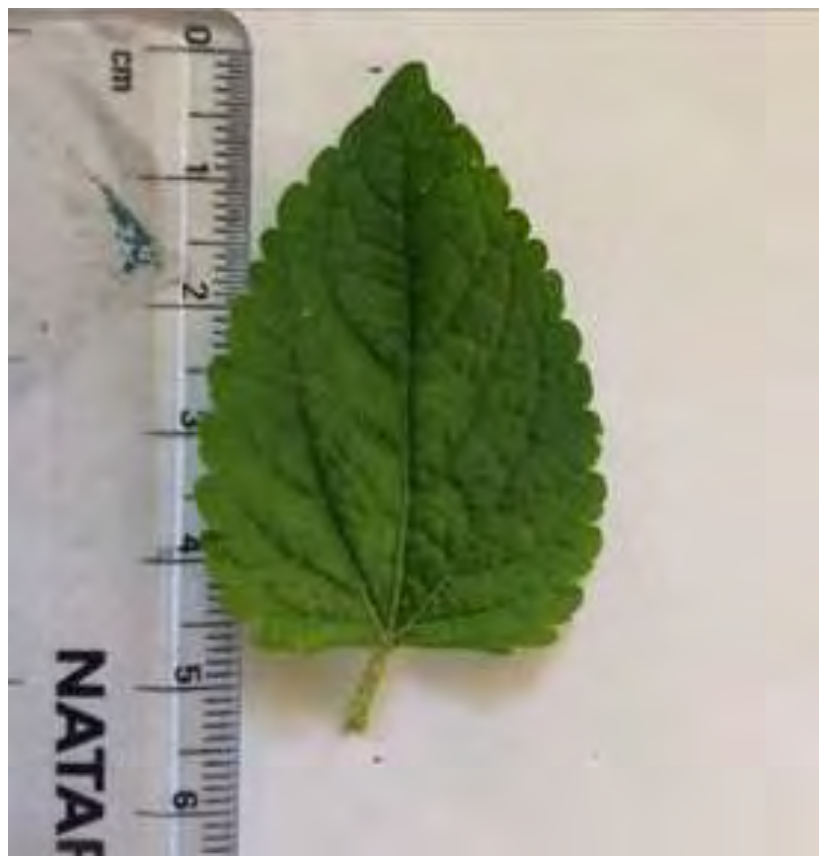

Figure 2: Leaf of Ageratum conyzoides. 
the stage of the projection microscope at 40x. Thus, the number of epidermal cells (E) in each field was counted in an area $60 \times 60 \mathrm{~mm}$. the stomatal index (I) were calculated using the formula-

$$
I=S \times 100 / E+S
$$

Determination of vein-islet and vein-termination number

Few leaves were cut and boiled in chloral hydrate solution in a clean beaker on water bath and mounted in glycerine water. The vein-islet and vein-termination were then subjected to a projection microscope at 40x. the number of vein-islet and vein-termination present was counted within the given square of $60 \times 60 \mathrm{~mm}$. The observations from four squares were taken and the mean was also calculated to get the average result.

\section{RESULT}

In this study, the pharmacognostic standards for the leaves of Ageratum conyzoides was carried out as follows:

\section{Macroscopic character}

Habitat: Ageratum conyzoides commonly grows in the proximity of habitation, annual herb with shallow, the flowers are purple, blueish or white.

Leaves: Leaves are pale green (Figures 1\&2), aromatic odour, pungent taste, arranged as opposite or the upper alternate, sub-acute, crenate with ciliate margins, hairy on both side with cuneate base, $30-70 \mathrm{~cm}$ tall. Petioles 1.1-1.5 cm long and are egg-shaped with broad end at base (ovate) up to $6.5 \mathrm{~cm}$ long (Table 1).

\section{Microscopic character}

T.S. of leaf showed upper and lower epidermis (Figure

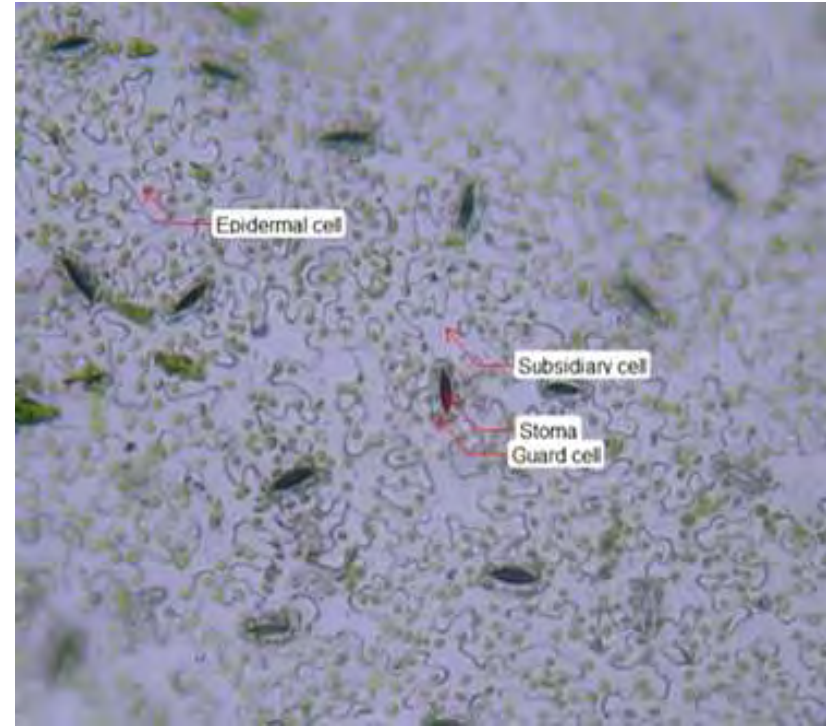

Figure 3: Epidermis of the leave of Ageratum conyzoides.
4). The vascular bundle is surrounded by parenchymatous cells, which is radiated with xylem and phloem. Anomocytic stomata are seen in both upper and lower epidermis (Figure 3).

Quantitative microscopy of leaf constants

The quantitative microscopy of leaf constants is shown in Figure 5 . The stomatal number, stomata index, vein islet number, vein termination number are comparatively constant for leaves and can be used to make out differences between closely related species and the results are depicted in Table 2.

\section{DISCUSSION}

The standardization of crude drugs is an integral part for determined its correct identification (Periyanayagam, 2013). Before any crude drug can be included in an herbal Pharmacopeia, pharmacognostic standard and parameters must be established. Macro and micro standards can be identifying parameters to authenticate the drug (Mahmood, 2005). The macroscopical characters of the plant can serve as valuable sources for diagnostic parameters (Karthikeyan, 2014).

Microscopic method is one of the simplest and cheapest methods to start for establishing the correct identification of the plant specimen (Agarwal, 2014). Transverse section of leaf only reported in the previous study. Standardization is an essential measure of quality, quantity, purity and authenticity (Kaur, 2018). The macroscopical character of the leaves such as colour, odour, taste, margin, base, apex and so forth were studied and thus can help for identification of the plant of Ageratum conyzoides. Microscopical evaluation revealed the present of trichomes, collenchyma and parenchyma, xylem and phloem (Santosh, 2016). Anomocytic stomata are also seen. This study can also help in identification of plant

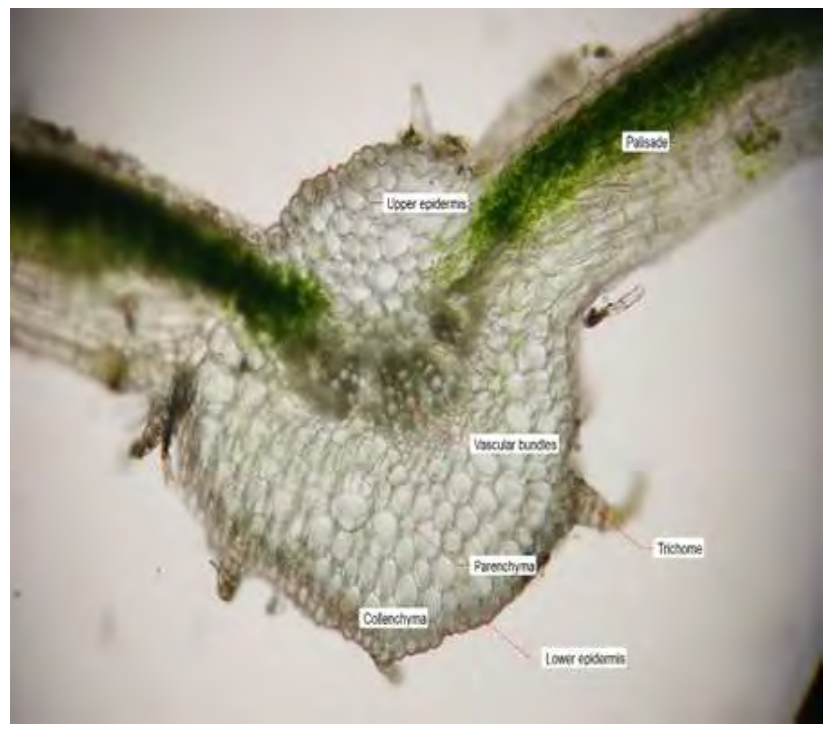

Figure 4: T.S. of leave of Ageratum conyzoides. 
Table 1: Macroscopical characters of the leaves of Ageratum conyzoides.

\begin{tabular}{|c|c|}
\hline Size & $4.4-5.2 \times 3.2-4.3 \mathrm{~cm}$ \\
\hline colour & Pale green \\
\hline odour & Aromatic \\
\hline taste & Pungent \\
\hline shape & Ovate \\
\hline margin & Crenate with ciliate \\
\hline apex & Sub-acute \\
\hline base & Cuneate \\
\hline
\end{tabular}

materials.

\section{CONCLUSION}

From the present study we can conclude that the information on quality, purity and identity of the plant material can be obtained from macroscopy, microscopy and quantitative parameters. These parameters can be utilising a quick identification of Ageratum conyzoides. The various details obtained from these studies (such as Morphology as well as pharmacognostic) will help in authentication and differentiation from other species of this genus and can be serve as a valuable source for diagnosis of the species and provide support to their quality control.

\section{ACKNOWLEDGEMENT}

The authors wish to thank Dr Chawngthanliana, Director, RIPANS, and Dr H. Lalhlenmawia, Head, Department of Pharmacy, for providing facilities to conduct this research work. We also thank to $\operatorname{Dr}$ A.A. Mao, Scientis-F \& Head of office, Botanical Survey of India (BSI), Shillong, for identification and authentication of plant species.

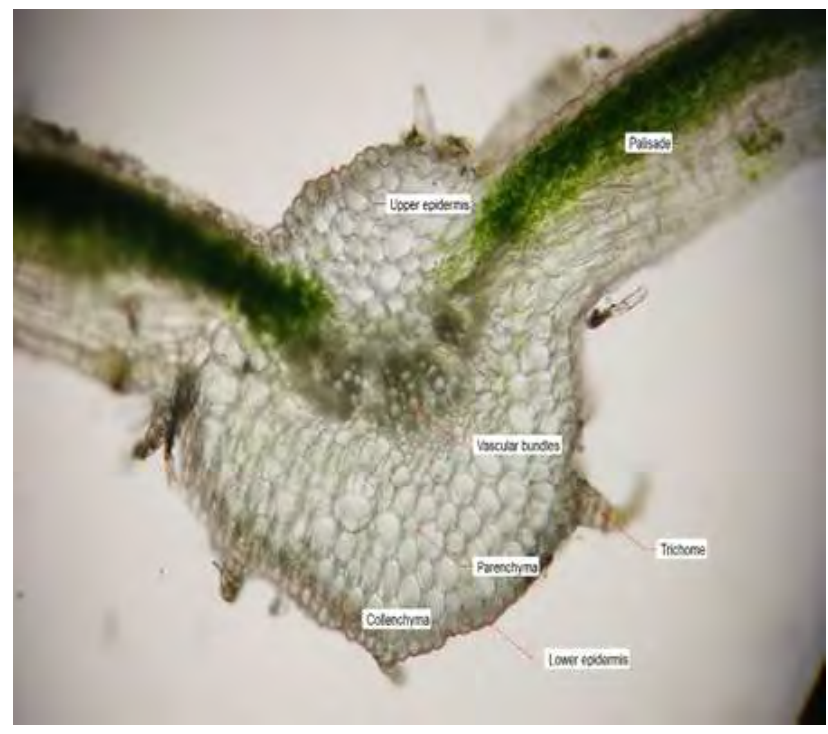

Figure 4: T.S. of leave of Ageratum conyzoides.
Table 2: Quantitative microscopy of leaf constants.

\begin{tabular}{|l|c|}
\hline \multicolumn{1}{|c|}{ Parameters } & Range \\
\hline Stomatal number (lower epidermis) & 5.25 \\
\hline Stomatal number (upper epidermis) & 4.75 \\
\hline Stomatal index (lower epidermis) & 58.6 \\
\hline Stomatal index (upper epidermis) & 65 \\
\hline Vein islet number & 2 \\
\hline Vein termination number & 3.5 \\
\hline
\end{tabular}

\section{REFERENCES}

Chintoju, N., Konduru, P., Kathula, R.L., Remella, R. (2015). Importance of natural products in the modern history. Research and Reviews: Journal of Hospital and Clinical Pharmacy, 1(1):5-10.

Dash, G.K., Murthy, P.N. (2011a). Wound healing effects of Ageratum conyzoides Linn. Int J Pharm Bio Sci., 2 (2): 369-383.

Dash, G.K., Murthy, P.N. (2011b). The wound healing effects of a new polyherbal formulation. Der Pharmacia Lettre, 3(1): 342-349.

Karthikeyan, V., Agrawal, S.K., Parthiban, P., Nandhini, S.R. (2014). Multivitamin plant: pharmacognostical standardization and phytochemical profile of its leaves. Journal of Pharmacy Research, 8(7): 910-915.

Kaur, R., Singh, B., Kaur, S. (2018). Pharmacognostic studies on leaves of Ageratum conyzoides Linn. Journal of Pharmacognosy and Phytochemistry; 7(3):3181-3185.

Khare, P., Khare, S., Goswami, R.B., Pathak, A.K. (2010). Evaluation of comparative effect of intact plant formulation \& its polyherbal formulation for wound healing activity. Plant Archives, 10(2): 671-4.

Khare, C.P. (2007). Indian M edicinal Plants: An Illustrated Dictionary. Allahabad (India): Lalit Mohan Basu.

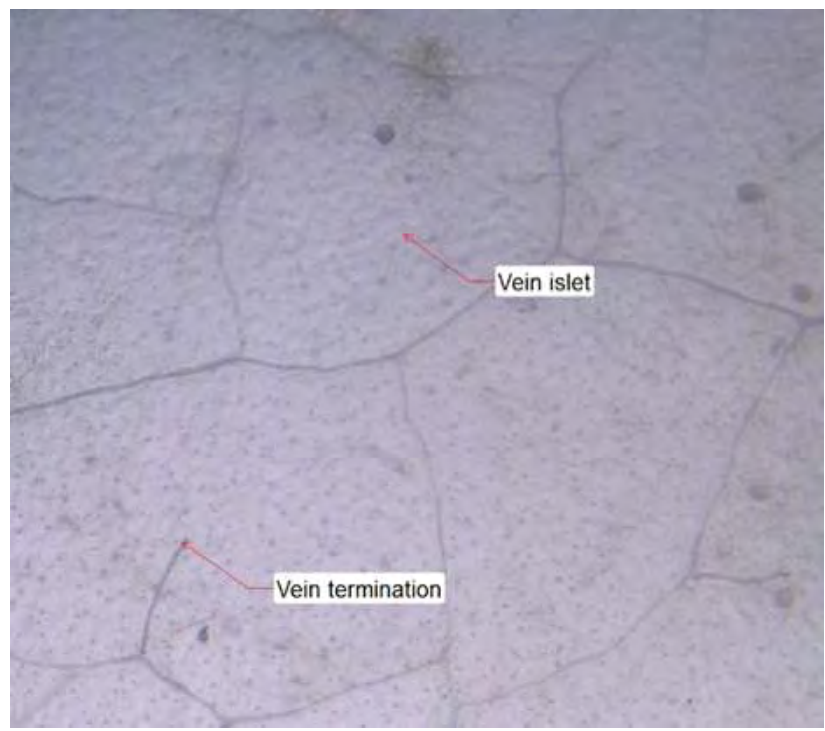

Figure 5: Vein islet and vein termination A. conyzoides. 
Kirtikar, K.R., Basu, B.D. (1993). Indian Medicinal Plants. Allahabad (India): Lalit Mohan Basu.

Moreira, M.D., Picanço, M.C., Barbosa, L.C.A., Guedes, R.N.C., Barros, E.C., Campos, M.R. (2007). Compounds from Ageratum conyzoides: Isolation, structure elucidation and insecticidal activity. Pest Manag Sci., 63 (6): 615-621.

Periyanayagam, K., Karthikeyan, V. (2013). Pharmacognostical, SEM and XRF profile of the leaves of Artocarpu sheterophyllus L. (Moraceae) - A contribution to combat the NTD. Innovare Journal of Life sciences, 1 (1): 23-28.

Santosh, R.F., Nunes, B.M., Sá, L.D., Soares, L.A.L., Randan, K.P. (2016). Morpho-anatomical study of Ageratum coonyzoides. Rev. Bras. Farmacogn, 26: 679-687.

Woldeyes, S., Adane, L., Tariku, Y., Muleta, D., Begashaw, T. (2012). Evaluation of antibacterial activities of compounds isolated from Sida rhombifolia Linn. (Malvaceae). Nat Prod Chem Res; 1(101):2. 